\title{
12 Studies within the European Union
}

As UMG has faced denial of transmission of personal data from participating hospitals in several European countries by virtue of legal obstacles, we have asked six partner law firms in European countries (Italy, Poland, Portugal, Serbia, Slovenia, Spain) to deliver a legal opinion on their national data protection regulations regarding the processing of personal data for the purpose of scientific research. In detail (cf. tab. 2), the first question aimed to see if the transmission of IDAT and documents containing IDAT to a central register in Germany is restricted by national regulations beyond GDPR (1.). Secondly, the question was asked whether in certain situations IDAT cannot be transferred to the central register in Germany despite the consent given by the patient and for legal reasons beyond GDPR (2.).

The legal information provided by the partner law firms dates from December 2018 and January 2019. In all relevant countries, the transposition of GDPR provisions into national law is still in progress. In principle, legal adjustments can be made at any time. In case of a specific research project in one of these countries, we therefore recommend reviewing the national regulations of the respective country. 
Tab. 2 Legal opinions on national data protection regulations regarding the processing of personal data for the purpose of scientific research from Italy, Poland, Portugal, Serbia, Slovenia and Spain

\begin{tabular}{|c|c|c|c|c|}
\hline \multirow[b]{2}{*}{ Country } & \multicolumn{2}{|c|}{$\begin{array}{l}1 . \\
\text { Regulations regarding the transmission of IDAT } \\
\text { to a central register (beyond } \\
\text { GDPR) }\end{array}$} & \multicolumn{2}{|c|}{$\begin{array}{l}2 . \\
\text { Particular use cases of illegal transfer } \\
\text { from IDAT to Germany despite the } \\
\text { consent of participant (beyond GDPR) }\end{array}$} \\
\hline & Regulatory Requirements & $\begin{array}{l}\text { Level of } \\
\text { restriction }\end{array}$ & Regulatory Requirements & $\begin{array}{l}\text { Level of } \\
\text { restriction }\end{array}$ \\
\hline Italy & $\begin{array}{l}\text { No additional restrictions } \\
\text { identified. } \\
\text { Italian Data Protection Autho- } \\
\text { rity confirmed the compatibi- } \\
\text { lity of the "General Authori- } \\
\text { sation to process of personal } \\
\text { data for scientific research } \\
\text { purposes" and the "Deonto- } \\
\text { logical Rules concerning the } \\
\text { process of personal data for } \\
\text { scientific research purposes" } \\
\text { with the GDPR. } \\
\text { To date, no specific measures } \\
\text { for the conduct of clinical trials } \\
\text { have been issued by the Itali- } \\
\text { an Data Protection Authority. }\end{array}$ & $*$ & $\begin{array}{l}\text { No additional } \\
\text { restrictions identified. } \\
\text { The Ethic Committees } \\
\text { approve also the used } \\
\text { forms of the } \\
\text { declaration of } \\
\text { consent; their } \\
\text { approval may vary. }\end{array}$ & $*$ \\
\hline Poland & $\begin{array}{l}\text { Restrictions possible if IDAT are } \\
\text { qualified as data of "medical } \\
\text { records" (if surnames, first } \\
\text { names, dates of birth, gender, } \\
\text { address or place of residen- } \\
\text { ce, social security numbers, } \\
\text { identification of the healthcare } \\
\text { providers or description of } \\
\text { the patient's health are con- } \\
\text { tained). } \\
\text { Without the patient's con- } \\
\text { sent, "medical records" data } \\
\text { can only be transferred to } \\
\text { universities and research } \\
\text { institutes, but IDAT shall not } \\
\text { be included. If the patient's } \\
\text { consent has been obtained, } \\
\text { IDAT can be transferred. }\end{array}$ & $* *$ & $\begin{array}{l}\text { Additional restrictions } \\
\text { identified. } \\
\text { In case of "medical re- } \\
\text { cord" data, the purpo- } \\
\text { ses of processing IDAT } \\
\text { shall be clearly defi- } \\
\text { ned in the patient's } \\
\text { declaration of consent. } \\
\text { In case of a "signifi- } \\
\text { cant experiment", a } \\
\text { prior positive voting of } \\
\text { a Bioethics committee } \\
\text { is required. } \\
\text { Depseudonymization } \\
\text { may be inadmissible. }\end{array}$ & $* *$ \\
\hline
\end{tabular}

43 The following visualizations stand for: * no additional restrictions identified; ** additional restrictions identified; *** transmission of IDAT illegal in certain cases 
Part II of the legal opinions: Detailed Questions on organisational and technical measures

\begin{tabular}{|c|c|c|c|c|}
\hline & $\begin{array}{l}1 . \\
\text { Regulations regarding the transm } \\
\text { to a central register (beyond } \\
\text { GDPR) }\end{array}$ & ission of IDAT & $\begin{array}{l}2 . \\
\text { Particular use cases of illeg } \\
\text { from IDAT to Germany desp } \\
\text { consent of participant (bey }\end{array}$ & $\begin{array}{l}\text { lal transfer } \\
\text { ite the } \\
\text { ond GDPR) }\end{array}$ \\
\hline Country & Regulatory Requirements & $\begin{array}{l}\text { Level of } \\
\text { restriction }\end{array}$ & Regulatory Requirements & $\begin{array}{l}\text { Level of } \\
\text { restriction }\end{array}$ \\
\hline Portugal & $\begin{array}{l}\text { No additional restrictions } \\
\text { identified. } \\
\text { The Ethics Committees ap- } \\
\text { prove the clinical trial by a } \\
\text { risk-benefit-evaluation, taking } \\
\text { into consideration also the } \\
\text { used forms of the declaration } \\
\text { of consent; their approval } \\
\text { may vary. } \\
\text { The sponsor of the clinical } \\
\text { study is responsible for com- } \\
\text { pliance with the legal require- } \\
\text { ments for processing IDAT. }\end{array}$ & $*$ & $\begin{array}{l}\text { Additional Restrictions } \\
\text { identified. } \\
\text { Information security } \\
\text { regulations to be com- } \\
\text { plied with. } \\
\text { IDAT have to be proces- } \\
\text { sed by persons subject } \\
\text { to a legal obligation of } \\
\text { professional secrecy. }\end{array}$ & $* *$ \\
\hline Serbia & $\begin{array}{l}\text { No additional restrictions } \\
\text { identified. } \\
\text { The Ethics Committee and the } \\
\text { Commissioner for the Protec- } \\
\text { tion of Personal Data approve } \\
\text { the used forms of the decla- } \\
\text { ration of consent and the } \\
\text { export of IDAT; their approval } \\
\text { may vary. } \\
\text { The intended processing of } \\
\text { IDAT (e.g. manner of proces- } \\
\text { sing) and the declaration of } \\
\text { consent (e.g. exact number } \\
\text { and names of persons IDAT } \\
\text { are disclosed to) have to be } \\
\text { described precisely. }\end{array}$ & $*$ & $\begin{array}{l}\text { Additional restriction } \\
\text { identified. } \\
\text { Export of IDAT to a } \\
\text { country that is not a } \\
\text { signatory to the Con- } \\
\text { vention on the Pro- } \\
\text { tection of Individuals } \\
\text { with regard to the } \\
\text { automatic processing } \\
\text { of personal data of the } \\
\text { Council of Europe is } \\
\text { illegal. }\end{array}$ & $* * *$ \\
\hline Slovenia & $\begin{array}{l}\text { No additional restrictions } \\
\text { identified. } \\
\text { IDAT cannot be transferred } \\
\text { by physically transferring the } \\
\text { original medical records or } \\
\text { documentation being part of } \\
\text { the original medical record. }\end{array}$ & $*$ & $\begin{array}{l}\text { No additional restricti- } \\
\text { ons identified. } \\
\text { Physical transfer } \\
\text { of original medical } \\
\text { records or documen- } \\
\text { tation being part of } \\
\text { the original medical } \\
\text { record cannot be con- } \\
\text { sented to. }\end{array}$ & $*$ \\
\hline
\end{tabular}




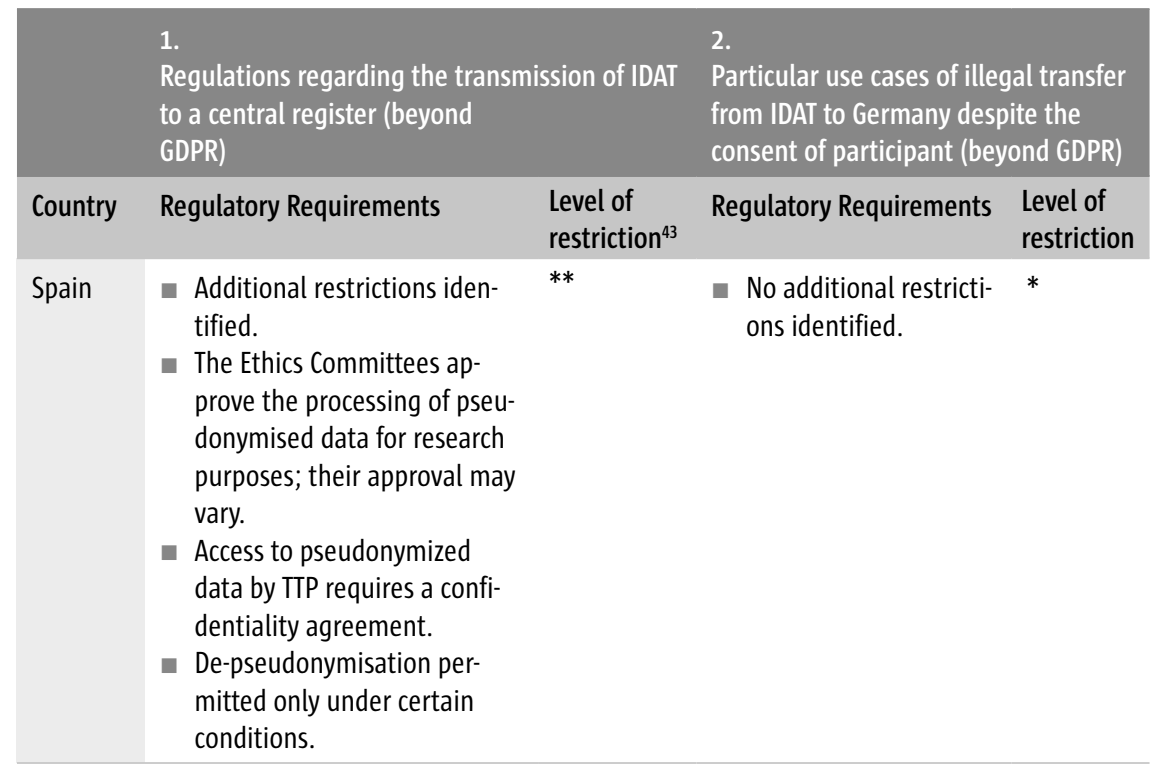

